\title{
Selective Separation of the Major Whey Proteins Using lon Exchange Membranes
}

\author{
S. Goodall, ${ }^{*}$ A. S. Grandison, ${ }^{* 1}$ P. J. Jauregi, ${ }^{*}$ and J. Price \\ *Department of Food Biosciences, University of Reading, Whiteknights, Reading RG6 6AP, United Kingdom \\ †Volac International Limited, Felinfach, Lampeter, Ceredigion, Wales, SA48 8AG, United Kingdom
}

\begin{abstract}
Synthetic microporous membranes with functional groups covalently attached were used to selectively separate $\beta$-lactoglobulin, BSA, and $\alpha$-lactalbumin from rennet whey. The selectivity and membrane performance of strong (quaternary ammonium) and weak (diethylamine) ion-exchange membranes were studied using breakthrough curves, measurement of binding capacity, and protein composition of the elution fraction to determine the binding behavior of each membrane. When the weak and strong anion exchange membranes were saturated with whey, they were both selective primarily for $\beta$-lactoglobulin with less than $1 \%$ of the eluate consisting of $\alpha$-lactalbumin or BSA. The binding capacity of a pure $\beta$-lactoglobulin solution was in excess of $1.5 \mathrm{mg} / \mathrm{cm}^{2}$ of membrane. This binding capacity was reduced to approximately $1.2 \mathrm{mg} / \mathrm{cm}^{2}$ when using a rennet whey solution $(\mathrm{pH}$ 6.4). This reduction in protein binding capacity can be explained by both the competitive effects of other whey proteins and the effect of ions present in whey. Using binary solution breakthrough curves and rennet whey breakthrough curves, it was shown that $\alpha$-lactalbumin and BSA were displaced from the strong and weak anion exchange membranes by $\beta$ lactoglobulin. Finally, the effect of ionic strength on the binding capacity of individual proteins for each membrane was determined by comparing model protein solutions in milk permeate ( $\mathrm{pH}$ 6.4) and a $10 \mathrm{mM}$ sodium phosphate buffer ( $\mathrm{pH}$ 6.4). Binding capacities of $\beta$-lactoglobulin, $\alpha$-lactalbumin, and BSA in milk permeate were reduced by as much as $50 \%$. This reduction in capacity coupled with the low binding capacity of current ion exchange membranes are 2 serious considerations for selectively separating complex and concentrated protein solutions.
\end{abstract}

Key words: whey protein, ion exchange membrane, selective separation

Received July 23, 2007.

Accepted September 5, 2007.

${ }^{1}$ Corresponding author: a.s.grandison@reading.ac.uk

\section{INTRODUCTION}

In large-scale processing of whey it is possible to use membrane processes or ion-exchange chromatography to produce 2 distinct types of products, whey protein concentrates and whey protein isolates, both of which contain all the whey proteins in the same proportions as in the original whey. There is an increasing need to produce individual whey proteins on a large scale without damaging protein structure or their functional properties.

The selective separation of individual whey proteins using membrane filtration has proved difficult due to the relatively similar physicochemical properties of the different proteins (Table 1). Good selective separation on the basis of size requires at least a 2 -fold difference in molecular weight and would therefore be limited to separating proteins such as $\alpha$-lactalbumin (14,000 Da) and immunoglobulins (15,000 to $1,000,000 \mathrm{Da})$. However, separating whey proteins on the basis of their isoelectric points gives 2 distinct groups: the major whey proteins: $\beta$-lactoglobulin, BSA, and $\alpha$-lactalbumin, which are negatively charged at the $\mathrm{pH}$ of rennet whey ( $\mathrm{pH} 6.2$ to 6.4); and minor whey proteins lactoferrin and lactoperoxidase that hold a positive net charge at the $\mathrm{pH}$ of whey. These distinct properties offer the possibility of selectively separating the groups using ion exchange chromatography and, more particularly, ion exchange membranes.

The principle behind ion exchange membrane separation is the reversible interaction between target protein and membrane functional groups (i.e., charged functional groups that are covalently attached to the membrane surface). Ion exchange membranes fall into 2 categories: anion exchange membranes and cation exchange membranes. Anion exchange membranes have positively charged functional groups such as quaternary ammonium or diethylamine and will theoretically bind $\beta$-lactoglobulin, $\alpha$-lactalbumin, and BSA, which are negatively charged at the $\mathrm{pH}$ of whey. The cation exchange membranes have negatively charged functional groups such as carboxylic and sulfonic acid and will, in theory, bind lactoferrin and lactoperoxidase, which are positively charged at the $\mathrm{pH}$ of whey. 
Table 1. Physiochemical properties of the major whey proteins (Etzel, 1995; Zydney, 1998)

\begin{tabular}{|c|c|c|c|c|}
\hline Protein & $\begin{array}{l}\text { Molecular weight } \\
(\mathrm{Da})\end{array}$ & $\begin{array}{l}\text { Isoelectric } \\
\text { point }\end{array}$ & $\begin{array}{c}\text { Concentration } \\
(\mathrm{g} / \mathrm{L})\end{array}$ & $\begin{array}{c}\text { Proportion } \\
\text { of total } \\
\text { whey }(\%)\end{array}$ \\
\hline$\beta$-Lactoglobulin & 18,300 & 5.35 to 5.49 & 3.0 & 40 to 55 \\
\hline$\alpha$-Lactalbumin & 14,000 & 4.2 to 4.5 & 1.2 & 11 to 20 \\
\hline Immunoglobulins & 15,000 to $1,000,000$ & 5.5 to 8.3 & 0.6 & 8 to 11 \\
\hline Bovine serum albumin & 69,000 & 5.13 & 0.3 & 4 to 12 \\
\hline Lactoferrin & 77,000 & 7.8 to 8.0 & 0.1 & 1 \\
\hline Lactoperoxidase & 77,500 & 9.2 to 9.9 & 0.002 & 1 \\
\hline
\end{tabular}

As well as defining the charge of a membrane, membranes are also categorized as weak or strong anion or cation exchange membranes, which relates to the degree of ionization of the functional groups. A typical functional group on a strong anion exchange membrane is quaternary ammonium, which is completely ionized over a wide $\mathrm{pH}$ range, whereas for weak anion exchange membranes, with functional groups such as diethylamine, the degree of dissociation between functional group and target protein is far more dependent on $\mathrm{pH}$. Strong anion exchangers are therefore only considered when the target protein requires extremes in $\mathrm{pH}$. However, in the case of whey, a weak anion exchange membrane would be preferable (Kanekanian and Lewis, 1986).

There are many advantages of using membrane chromatography over column chromatography. The rate of association between target proteins and functional groups in ion exchange membranes is very rapid, unlike the slow rate of diffusion through packed columns. The fast convective flow combined with negligible pressure drop limitations exhibited by the thin membranes mean that processing times are dramatically reduced compared with packed columns (Weinbrenner and Etzel, 1994). Existing whey processors could benefit from the similarities between ion exchange membrane and existing ultrafiltration membrane in terms of processing configurations. It is possible to replace existing ultrafiltration membranes with ion exchange membranes without the need for expensive changes in plant (Etzel, 1995). A further advantage of using ion exchange membranes is their ease of scale-up and operation without the need for lengthy column packing procedures. A distinct advantage of pressure driven ion exchange processes is that there are no heat-treatments, extremes of $\mathrm{pH}$, or chemical pretreatment that could compromise protein structure and functionality (Drioli and Romano, 2001). Hence, development of ion exchange membranes would be most desirable in terms of purifying individual whey proteins for use in functional foods and pharmaceutical products.

Most earlier work on the use of ion exchange to selectively separate whey proteins has focused on the use of packed columns (e.g., Skudder, 1985; Turhan and Etzel, 2004). Of the limited studies on ion exchange membranes, most have concentrated on the use of cation exchange membranes. Using commercially available cation exchange membranes with pore sizes of 3 to $5 \mu \mathrm{m}$, rennet whey was fractionated to produce a protein stream of lactoferrin and lactoperoxidase, or streams with individual protein purity as high as 95\%, using differences in salt concentration (Chiu and Etzel, 1997; Ulber et al., 2001). Compared with column-based processes, flow rate was increased by up to 20 -fold with no reduction in binding capacity over many cycles. This application is particularly suited to separating proteins such as lactoferrin and lactoperoxidase, which are present in low concentration. However, it was emphasized that the binding capacities of membranes currently available are lower than the binding capacities achieved with bead packed columns with similar geometries, due to the greater surface area achieved when using beads. The advantages of membrane processing are therefore considered in terms of their shorter processing times and hence reduced costs.

Strong anion exchange membranes have also been studied and selectivity for different proteins determined under various conditions such as $\mathrm{pH}$. For instance, by passing clarified whey through a strong anion exchange membrane at $\mathrm{pH} 4.6,4.8$, and 5.0 , it was demonstrated that $\alpha$-lactalbumin bound to the membrane, whereas $\beta$-lactoglobulin, positively charged at these $\mathrm{pH}$ values, passed through the membrane (Bhattacharjee et al., 2006). This study used ion exchange membranes with extremely small loading volumes (250 $\mu \mathrm{L})$. Larger ion exchange membrane units have been studied using model solutions of BSA, $\beta$-lactoglobulin, and $\alpha$-lactalbumin on strong anion exchange membranes (Weinbrenner and Etzel, 1994) to investigate protein competition. Using solutions containing the 2 proteins, it was demonstrated that $\alpha$-lactalbumin could be displaced from the membrane by BSA, suggesting the possibility of selective elution processing, where all proteins bind to the membrane. There is also the possibility of utilizing selective adsorption of $\beta$-lactoglobulin, which has not hitherto been reported in this 
system. Other studies have investigated the membrane performance in terms of percentage protein recovery and binding capacities but have mainly focused on small scale strong exchangers (Adisaputro et al., 1996), whereas fewer studies have looked at the weak anion exchange membrane (Splitt et al., 1996).

The aim of this study was to determine protein selectivity using ion exchange membranes, in particular the use of weak anion exchange membranes compared with strong anion exchange membranes. Single protein, binary protein, and whey solutions were investigated to study i) membrane binding capacity, ii) protein-protein competition, iii) protein-ion competition, and iv) the effects of protein loading on selectivity.

\section{MATERIALS AND METHODS}

\section{Ion Exchange Membranes}

Sartobind MA ion exchange units were used (Sartorious AG, Goettinger, Germany). The reinforced stabilized cellulose membranes have a pore size of 3 to $5 \mu \mathrm{m}$ and functional groups covalently attached to the inner surface of the membranes. A weak anion exchanger with diethylamine groups (D-type) and a strong anion exchanger with quaternary ammonium groups were used (Q-type). Two membrane sizes were used: the first a unit made up of 3 stacked sheets with an effective adsorption area of $15 \mathrm{~cm}^{2}$ and a membrane volume of $0.41 \mathrm{~mL}$ (MA15); the second, a unit of 15 layers with an effective adsorption area of $75 \mathrm{~cm}^{2}$ and a membrane volume of $2.1 \mathrm{~mL}$ (MA75). Each membrane was $25 \mathrm{~mm}$ in diameter and $275 \mu \mathrm{L}$ thick; $1 \mathrm{~mL}$ of membrane volume is equal to $36.4 \mathrm{~cm}^{2}$ of membrane area. The MA15 unit was used in experiments to determine the breakthrough curves of single protein solutions on strong and weak anion exchangers and breakthrough curves of protein standards in buffer and milk permeate. All other experiments used the MA75 membrane unit.

\section{Breakthrough Curves of Single Protein Solutions on Strong and Weak Anion Exchangers}

Single protein solutions of $\beta$-lactoglobulin (L0130, Sigma, Dorset, UK), $\alpha$-lactalbumin (L5385, Sigma), and BSA (A2153, Sigma) were prepared in sodium phosphate buffer $(0.01 M, \mathrm{pH} 6.0)$ to a concentration of 1 $\mathrm{mg} / \mathrm{mL}$ and sterile filtered through a $0.2-\mu \mathrm{m}$ syringe filter. Membrane units (MA15) were first equilibrated with the same buffer before loading the protein solution. Permeate fractions were collected every $5 \mathrm{~mL}$ and protein concentration determined using absorbance at 280 nm (Ce1021 spectrophotometer, Cecil Instruments Ltd., Cambridge, UK). Calibration curves for all 3 proteins were performed at $280 \mathrm{~nm}$. After the protein was loaded, the membrane was washed with $30 \mathrm{~mL}$ of equilibration buffer to remove unbound protein. Bound protein was eluted with a $1 M \mathrm{NaCl}$ prepared in equilibration buffer. All solutions were loaded onto the membrane using a $50-\mathrm{mL}$ syringe at an approximate flow rate of $10 \mathrm{~mL} / \mathrm{min}$. Membranes were regenerated with $0.2 M$ sodium hydroxide solution between cycles. All membranes were stored in $1 \mathrm{M} \mathrm{KCl}$ in $20 \%$ ethanol.

\section{Breakthrough Curves of Binary Protein Solutions on Strong and Weak Anion Exchange Membranes}

Binary protein solutions with equal concentrations $(1 \mathrm{mg} / \mathrm{mL}$ ) of BSA and $\beta$-lactoglobulin were prepared in sodium phosphate buffer $(0.01 M, \mathrm{pH} 6.0)$. Batches of $350 \mathrm{~mL}$ of the binary solution were passed through the strong exchanger, whereas $300 \mathrm{~mL}$ was passed through the weak anion exchanger, due to its lower binding capacity. Experiments were performed on the MA75 unit. Fractions were collected every $5 \mathrm{~mL}$ and analyzed using reversed phase HPLC (Casal et al., 2006). The method uses a C4 Jupiter column (300 A, $250 \times 4.6 \mathrm{~mm}$ i.d. $5 \mu \mathrm{m}$, Phenomenex, Cheshire, UK) operating at a flow rate of $1 \mathrm{~mL} / \mathrm{min}$; solvent A, $0.1 \%$ (wt/vol) trifluoroacetic acid in water; solvent B, $0.085 \%$ trifluoroacetic acid in water:acetonitrile (90:10). The elution was performed as follows: 0 to $60 \mathrm{~min}$, a linear gradient by increasing solvent B from 20 to $50 \%$; 60 to $65 \mathrm{~min}, 50 \%$ solvent $\mathrm{B}$ in isocratic mode; 65 to $65.5 \mathrm{~min}$, 50 to $100 \%$ solvent B; 65.5 to $71 \mathrm{~min}, 100 \%$ solvent B in isocratic mode.

\section{Whey Preparation}

Rennet whey was prepared from raw bulk milk obtained from the university farm (Fonteh, 2001). Milk was heated to $30^{\circ} \mathrm{C}$ and $0.03 \%$ (vol/vol) of commercial rennet (Chymax, CHR Hansen UK Ltd., Berks, UK) was added. The milk was stirred for $5 \mathrm{~min}$ and then further incubated for $1 \mathrm{~h}$, allowing the caseins to coagulate. After $1 \mathrm{~h}$ the curds were cut to allow the whey to drain and were then further incubated for $30 \mathrm{~min}$ before being filtered using cheesecloth. The whey was then filtered through Whatman paper no. 4 (Thermo Fisher Scientific, Leicester, UK) followed by centrifuging at $11,900 \times g$ for $30 \mathrm{~min}$ at $4^{\circ} \mathrm{C}$.

\section{Breakthrough Curves of Rennet Whey on Strong and Weak Anion Exchangers}

Whey protein concentration was determined using the bicinchonic acid method (Smith et al., 1985). A BSA standard solution was used to prepare a calibration curve, linear between 0 and $0.8 \mathrm{mg} / \mathrm{L}$. After whey pro- 
tein concentration was determined the whey was diluted in sodium phosphate buffer $(0.01 M, \mathrm{pH} 6.0)$ to a concentration of $1 \mathrm{mg} / \mathrm{mL}$. Three different volumes (50, 100 , and $300 \mathrm{~mL}$ ) of whey were then loaded onto the strong and weak anion exchange membranes. All experiments used an MA75 unit. Permeate fractions were collected every $5 \mathrm{~mL}$; wash and eluate fractions were collected every $10 \mathrm{~mL}$; and all were analyzed using HPLC to determine total $\beta$-lactoglobulin, $\alpha$-lactalbumin, and BSA concentration.

\section{Breakthrough Curves of BSA and $\beta$-Lactoglobulin Standards in Buffer and Milk Permeate}

Single solutions of BSA and $\beta$-lactoglobulin were prepared in sodium phosphate buffer $(0.01 M, \mathrm{pH} 6.4)$ to a concentration of $1 \mathrm{mg} / \mathrm{mL}$. Single solutions of BSA and $\beta$-lactoglobulin were also prepared to $1 \mathrm{mg} / \mathrm{mL}$ in milk ultrafiltration permeate ( $\mathrm{pH} 6.4$ ), produced by ultrafiltration of skim milk using 25,000 molecular weight cut-off membranes. Single protein solutions in both sodium phosphate buffer and milk permeate were loaded onto a strong and weak anion exchanger, washed, eluted, and regenerated. Permeate and elution fractions were analyzed using HPLC. Experiments were carried out on an MA15 membrane unit.

\section{RESULTS AND DISCUSSION}

\section{Breakthrough Curves of Single Protein Solutions}

This series of experiments was carried out to ascertain whether all 3 of the major whey proteins, $\beta$-lactoglobulin, BSA, and $\alpha$-lactalbumin, bound to the strong and weak anion exchange membranes and to estimate binding capacity. Membrane binding capacity was calculated as the amount of protein loaded onto the membrane minus the total protein found in the permeate and wash fractions. After passing single standard protein solutions through both the strong and weak anion exchanger, it was determined that all 3 proteins bound to both membranes (Figure 1), as expected from their isoelectric points. All 3 proteins are negatively charged at the $\mathrm{pH}$ of rennet whey ( $\mathrm{pH} 6.2$ to 6.4). Although the 3 proteins bound to both membranes, the binding capacity of the weak anion exchanger was lower for all 3 proteins. However, this was consistent with the stated manufacturers minimum binding capacity for the MA15 units, using a test protein (BSA), of the weak anion exchanger $\left(0.6 \mathrm{mg} / \mathrm{cm}^{2}\right)$ and the stated minimum binding capacity of the strong anion exchanger $(0.8$ $\mathrm{mg} / \mathrm{cm}^{2}$ ).

Interestingly, the binding capacity of $\beta$-lactoglobulin was considerably higher than $\alpha$-lactalbumin and BSA. This higher binding capacity can not be explained fully

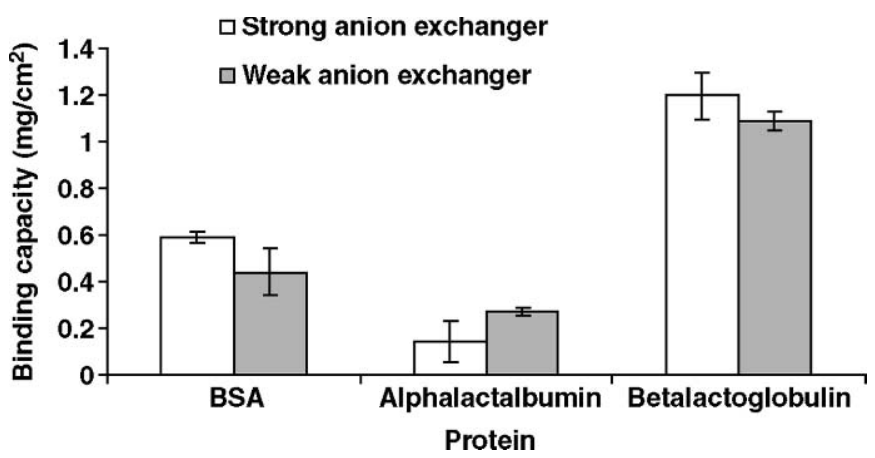

Figure 1. Binding capacity $\left(\mathrm{mg} / \mathrm{cm}^{2}\right)$ of $\beta$-lactoglobulin, $\alpha$-lactalbumin, and BSA on the strong and weak anion exchange membranes (MA15). Error bars represent the range of binding capacities from duplicate trials.

by molecular weight differences. At pH 6.0, $\beta$-lactoglobulin exists as a dimer and therefore has an effective molecular weight of $36,000 \mathrm{Da}$, whereas $\alpha$-lactalbumin has a molecular weight of $14,000 \mathrm{Da}$. Although it might therefore be expected that $\beta$-lactoglobulin would bind about twice as much as $\alpha$-lactalbumin, it does not explain the greater differences seen in Figure 1. Nor can it be explained fully by size with $\beta$-lactoglobulin having a radius of $3.5 \mathrm{~nm}$ (dimer), BSA $4 \mathrm{~nm}$, and $\alpha$-lactalbu$\min 1.8 \mathrm{~nm}$ (de Wit, 1998). One factor to consider is the structure of these 3 proteins at the $\mathrm{pH}$ of whey. $\beta$ Lactoglobulin is considered to be a very compact globular structure and most importantly exists as a dimer between $\mathrm{pH} 3.5$ and $\mathrm{pH} 7.5$ (Fox and McSweeney, 2003), whereas $\alpha$-lactalbumin and BSA are also globular structures but exist in monomeric form. As a dimer, $\beta$ lactoglobulin could have increased binding capacity if the dimer were aligned on the membrane in such a way as not to impede further dimers from coming into contact with binding sites. A further possibility in explaining binding behavior is that $\beta$-lactoglobulin could be disassociating into its monomeric form on association with the membrane functional group, although there is no evidence for this.

\section{Breakthrough Curves of Binary Protein Solutions on Strong and Weak Anion Exchange Membranes}

Having established that both the strong and weak anion exchange membranes would bind all 3 of the major whey proteins individually the next step was determine their selectivity using a binary solution of BSA and $\beta$-lactoglobulin. In a binary solution, as well as differences in individual binding capacities the effects of protein competition could also be studied. Binding behavior could be established by looking at the saturation curves (Figure $2 a$ and $b$ ) of each membrane. In 

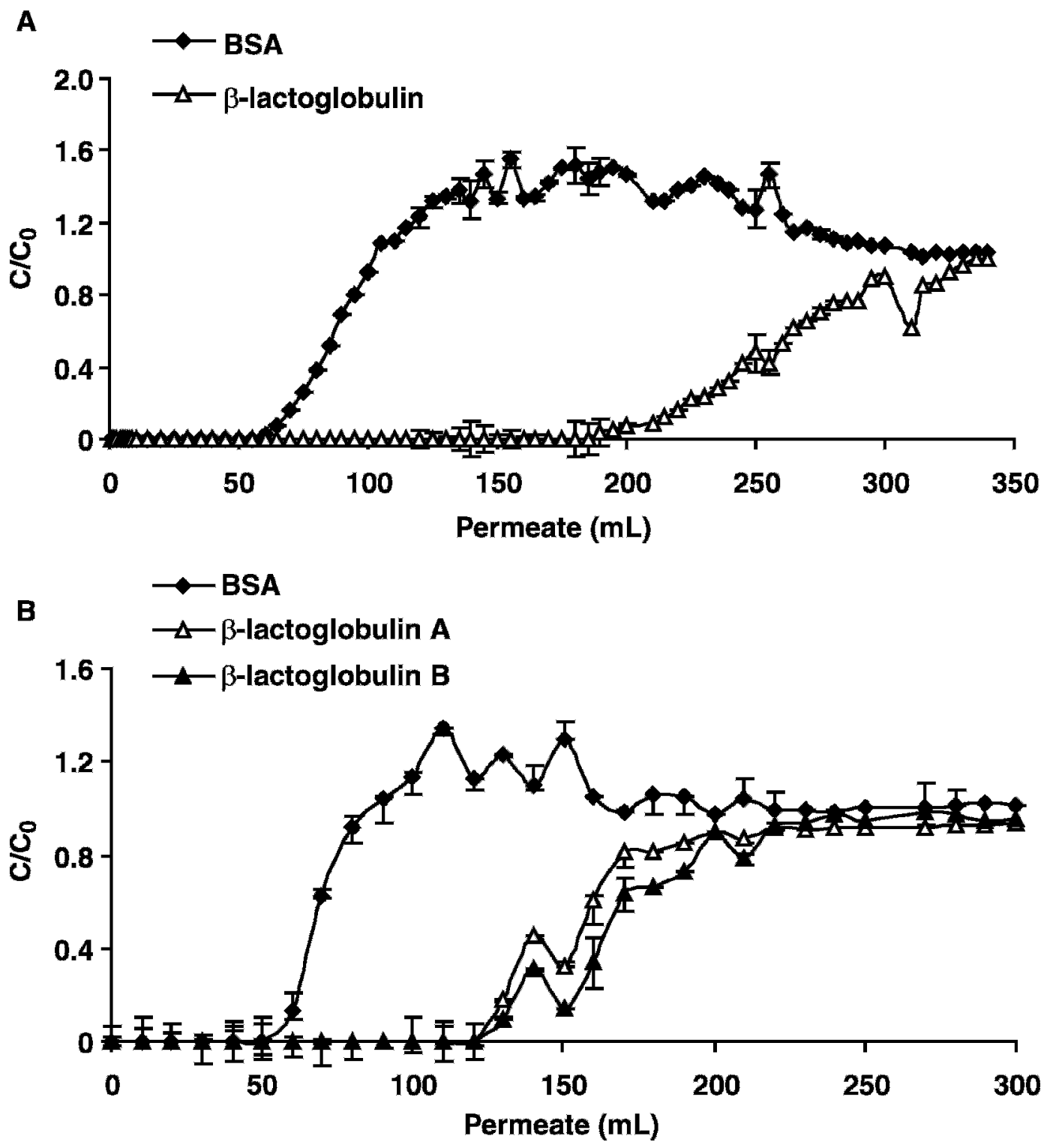

Figure 2. a) Permeate protein concentration (C) expressed as a proportion of the feed concentration $\left(\mathrm{C}_{0}\right)$ after passing $350 \mathrm{~mL}$ of a $1 \mathrm{mg}$ of protein/mL of binary protein solution through a strong anion exchange membrane (MA75). Error bars represent the range of results from duplicate trials. b) Permeate protein concentration $(\mathrm{C})$ expressed as a proportion of the feed concentration $\left(\mathrm{C}_{0}\right)$ after passing $300 \mathrm{~mL}$ of a $1 \mathrm{mg}$ of protein/mL of binary protein solution through a weak anion exchange membrane (MA75). Error bars represent the range of results from duplicate trials.

both the strong and weak ion exchange membranes, the first protein to appear in the permeate was BSA, which then rose sharply to a concentration above the feed concentration $\left(\mathrm{C} / \mathrm{C}_{0}>1\right)$ before falling back down to the feed concentration $\left(\mathrm{C} / \mathrm{C}_{0}=1\right)$; meanwhile, $\beta$-lactoglobulin concentration rose steadily to reach the feed concentration. This rise in concentration of BSA above the feed concentration is an indication that BSA is the weaker binding protein and is displaced from the membrane by $\beta$-lactoglobulin. The displacement of BSA from the membrane was more apparent in the strong anion exchanger with the permeate concentration of BSA reaching $150 \%$ of the feed concentration. The composition of the elution fraction shows that only $5 \%$ of the protein eluted from the strong anion exchanger was BSA whilst $21 \%$ of the protein eluted from the weak exchanger was BSA. The competitive effect of $\beta$-lactoglobulin is greater in the strong anion exchanger. A similar competitive behavior had previously been reported using binary solutions of BSA and $\alpha$-lactalbu- 
min, where $\alpha$-lactalbumin was displaced from the membrane by BSA causing the permeate concentration of $\alpha$-lactalbumin to rise to a concentration of $145 \%$ of the feed concentration (Weinbrenner and Etzel, 1994). If this is the case it would mean that the binding strength of the three major whey proteins was in this order: $\beta$ lactoglobulin $>$ BSA $>\alpha$-lactalbumin. The competitive nature of whey proteins would mean that a selective elution process, whereby all the proteins in whey are first adsorbed onto the membrane and then individually eluted, would not be possible unless the binding capacity far exceeded the whey protein concentration. However, it is possible to produce elution fractions containing predominantly $\beta$-lactoglobulin, and prior to $\beta$ lactoglobulin breaking through into the permeate, a permeate enriched in BSA could be collected.

\section{Breakthrough Curves of Rennet Whey on Strong and Weak Anion Exchangers}

Having established binding behavior using single and binary protein solutions, a set of experiments was conducted to determine the protein binding characteristics of whey. The membranes were saturated with a $1 \mathrm{mg}$ of protein $/ \mathrm{mL}$ of solution of rennet whey, and permeate fractions were collected every $5 \mathrm{~mL}$ and analyzed for individual protein composition to determine if the membranes had been saturated (Figure $3 \mathrm{a}$ and $3 \mathrm{~b})$. Elution fractions were also analyzed to establish membrane selectivity at 50,100, and $300 \mathrm{~mL}$ loading of a $1 \mathrm{mg}$ of protein/mL of solution of whey (Figure 4). Membrane performance was characterized in terms of i) total protein bound to the membrane ( $\beta$-lactoglobulin, BSA, and $\alpha$-lactalbumin); ii) total protein ( $\beta$-lactoglobulin, BSA, and $\alpha$-lactalbumin) found in eluate (mg); iii) total protein ( $\beta$-lactoglobulin, BSA, and $\alpha$-lactalbumin) recovered in the permeate, wash, and elution fractions as a percentage of the original feed; and iv) total protein ( $\beta$-lactoglobulin, BSA, and $\alpha$-lactalbumin) recovered in the elution fraction as a percentage of the protein that was bound to the membrane (Figures 5 and 6 ).

The protein binding behavior in both membranes (Figure 3 ) was very similar in that BSA and $\alpha$-lactalbumin broke through into the permeate and rose to a concentration above the feed concentration as they were displaced from the membrane by $\beta$-lactoglobulin. It is unclear from this study whether BSA or $\alpha$-lactalbumin is the stronger binding protein. Both BSA and $\alpha$-lactalbumin were seen in the permeate and reached saturation at the same point. As mentioned in the previous section, a study was carried out which suggests that BSA is capable of displacing $\alpha$-lactalbumin (Fuda and Jauregi, 2006). The composition of the elution fractions (Figure 4) shows that when the strong and weak anion exchangers were saturated $(300 \mathrm{~mL})$, the only protein that bound to the membrane was $\beta$-lactoglobulin with $\alpha$-lactalbumin present at lower than $1 \%$ of the total elution fraction. It is only when the protein solution loaded was reduced to $50 \mathrm{~mL}$ that all 3 of the major whey proteins can be seen in the elution fraction. At a $50 \mathrm{~mL}$ loading of the weak anion exchange membrane, the protein composition of the elution fraction was similar to that found in whey. However, the strong exchanger showed that some selectivity occurs at $50 \mathrm{~mL}$ as the elution fraction contained a higher proportion of BSA than that found in whey. In terms of selective separation of the major whey proteins, at the point of saturation both the strong and weak anion exchangers have a high selectivity for $\beta$-lactoglobulin and produce a permeate stream enriched in BSA and $\alpha$-lactalbumin.

Membrane binding capacity was measured after 300 $\mathrm{mL}$ of rennet whey had been loaded to ensure that the membrane was saturated. The binding capacities of the strong and weak anion exchangers were 1.23 and 1.17 $\mathrm{mg} / \mathrm{cm}^{2}$, respectively, confirming results seen with single and binary solutions, which showed that the weak anion exchanger has a lower binding capacity. These results also showed that the binding capacity was higher than the manufacturers' stated binding capacities for the strong and weak anion exchangers of 0.8 and $0.6 \mathrm{mg} / \mathrm{cm}^{2}$, respectively. However, the test protein was $\mathrm{BSA}$ at $\mathrm{pH} 7$, whereas the only protein bound to the membrane when whey was passed was $\beta$-lactoglobulin. The binding capacities of both membranes were lower for whey than for pure protein solutions. As single protein solutions, the binding capacities of $\beta$-lactoglobulin were 1.73 and $1.57 \mathrm{mg} / \mathrm{cm}^{2}$ on the strong and weak exchanger respectively. Single solutions of BSA had binding capacities of 1.48 and $1.45 \mathrm{mg} / \mathrm{cm}^{2}$ on the strong and weak anion exchanger. When whey was passed through a strong and weak anion exchanger to the point of saturation, the only protein bound to the membrane was $\beta$-lactoglobulin; therefore, binding capacities may be expected to be similar to those found with pure protein solutions (i.e., 1.73 and $1.57 \mathrm{mg} / \mathrm{cm}^{2}$ ). However, binding capacities reduced to 1.23 and $1.17 \mathrm{mg} / \mathrm{cm}^{2}$ on the strong and weak exchangers. This reduction in binding capacity is likely to be the result of the presence of ions in whey, which would be consistent with the findings of the following section. Also other proteins in whey (e.g., negatively charged glycomacropeptide) may compete for binding sites.

The binding capacities in terms of membrane area were approximately $1.23 \mathrm{mg} / \mathrm{cm}^{2}$ for the strong exchanger and $1.17 \mathrm{mg} / \mathrm{cm}^{2}$ for the weak exchanger. These indicate that processing $1 \mathrm{~kg}$ of a single protein would require up to $80 \mathrm{~m}^{2}$ of membrane in the current geometry. Stacked membrane units would need to be coupled 


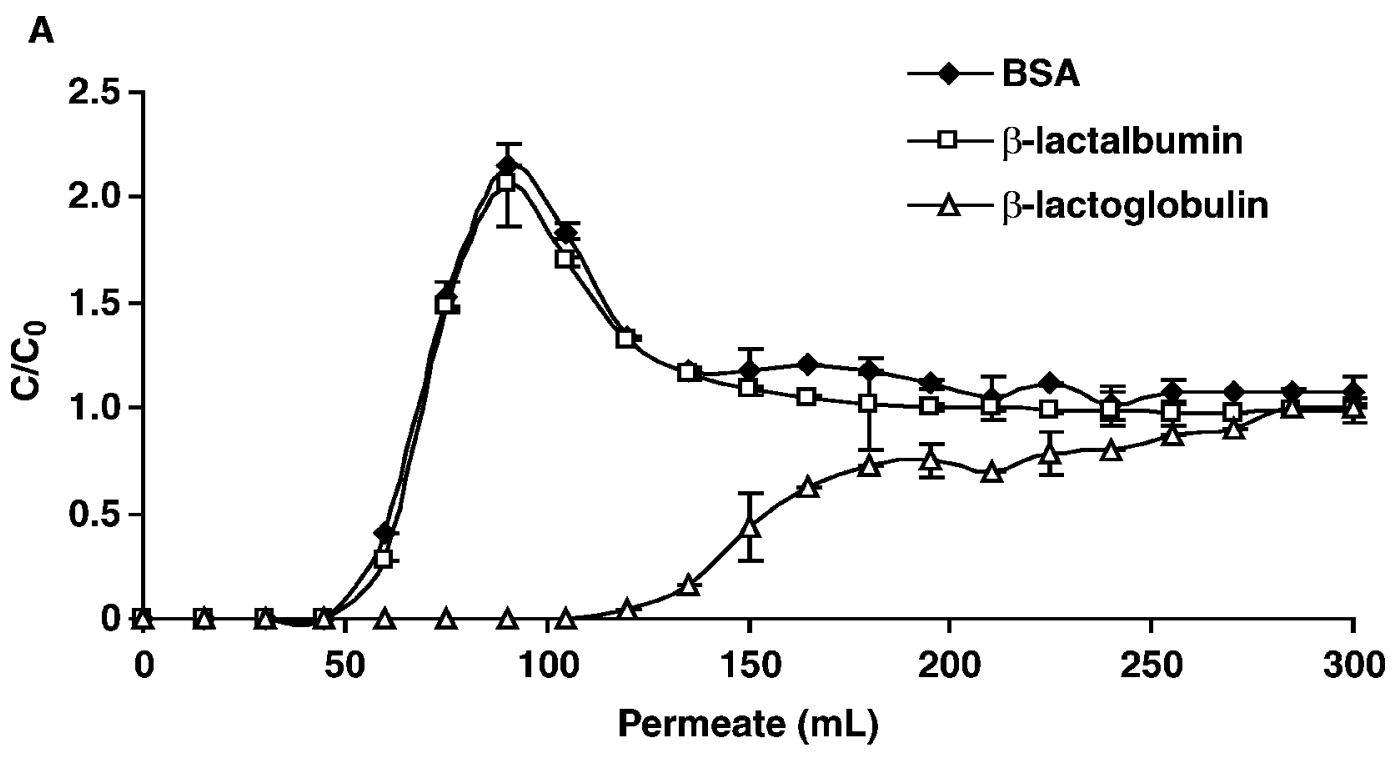

B

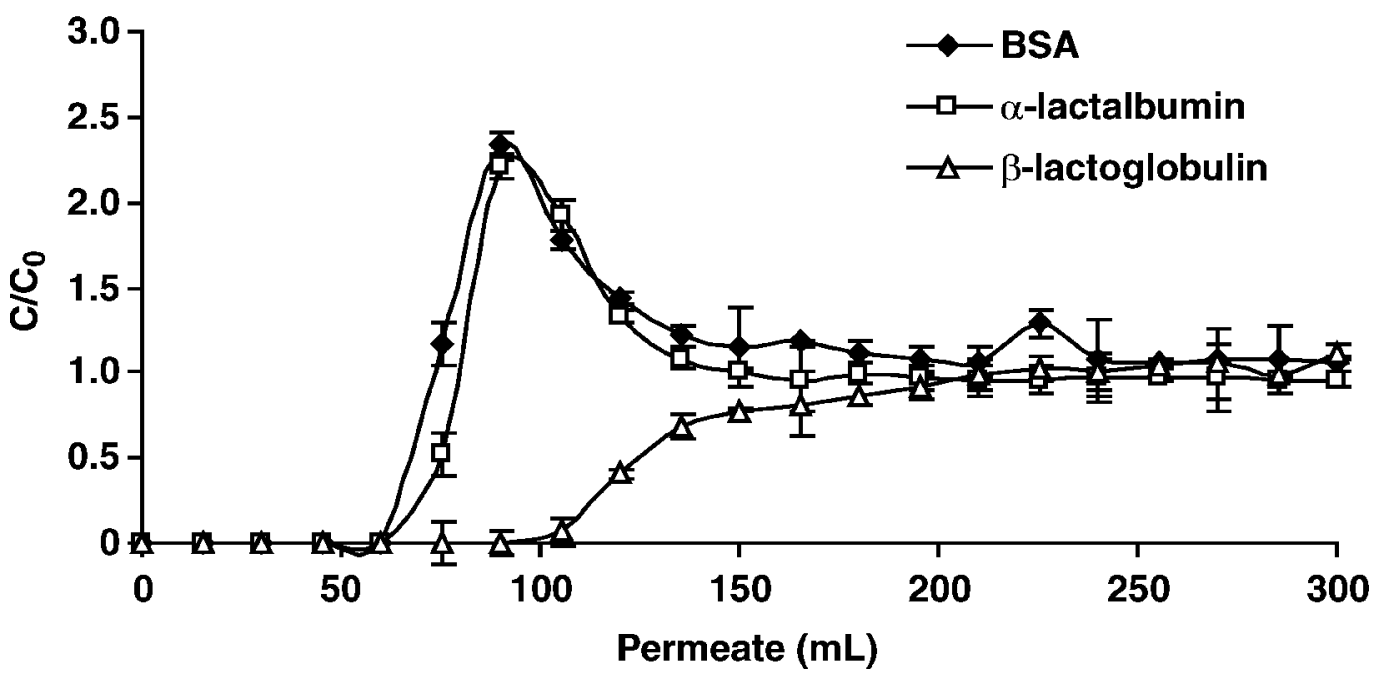

Figure 3. a) Individual protein concentrations in the permeate $(C)$ as a proportion of the feed concentration $\left(\mathrm{C}_{0}\right)$ after loading $300 \mathrm{~mL}$ of a $1 \mathrm{mg}$ of protein/mL of whey solution through a strong anion exchange membrane (MA75). Error bars represent the range of results from duplicate trials. b) Individual protein concentrations in the permeate $(C)$ as a proportion of the feed concentration $\left(\mathrm{C}_{0}\right)$ after loading $300 \mathrm{~mL}$ of a $1 \mathrm{mg}$ of protein/mL of whey solution through a weak anion exchange membrane (MA75). Error bars represent the range of results from duplicate trials.

in series and parallel to process large volumes of whey. Alternatively binding capacity could be increased by increasing the number of functional groups available on the membrane surface. An important processing parameter is the total protein recovered in the permeate, wash, and elution steps compared with the initial feed, which in all cases was greater than $85 \%$. However, in commercial processing a loss of up to $15 \%$ protein would be unacceptable. The method of determining protein concentrations in small subfractions rather than as total permeate, eluate, and wash solutions may have led to an underestimate of protein recovery in these experiments. The protein loss would need further consideration in terms of membrane performance after repeated cycling with and without washing steps, with a more suitable quantitative method.

In terms of protein loading, it is worth noting that as the protein loading increased to $300 \mathrm{~mL}$ (Figure 6) the protein recovery in the elution fraction from the mass bound to the membrane was reduced to as little as $70 \%$, implying that overloading the membrane can reduce membrane performance resulting in the need 




Figure 4. Protein compositions (\%) of the elution fractions recovered after loading 50, 100, and $300 \mathrm{~mL}$ of a diluted whey (1 mg of protein/ $\mathrm{mL}$ ) onto a strong anion exchanger (Q75) and a weak anion exchanger (D75) compared with the protein composition of the whey feed. Error bars represent the range of protein composition (\%) from duplicate trials.

for longer elution steps, increasing the overall processing time.

\section{Breakthrough Curves of BSA Standard in Buffer and Milk Permeate}

The competitive effect for binding sites exhibited by ions present in whey was investigated by comparing the binding capacity of protein solutions in a $10 \mathrm{mM}$ sodium phosphate buffer and protein solutions in milk permeate (Figure 7). In all cases the binding capacity was reduced by up to $50 \%$. It has previously been reported (Adisaputro et al., 1996) that due to whey proteins binding ions such as sulfates and phosphates, they can bind to the anion exchange membrane along with, or in preference to, whey proteins, hence reducing the

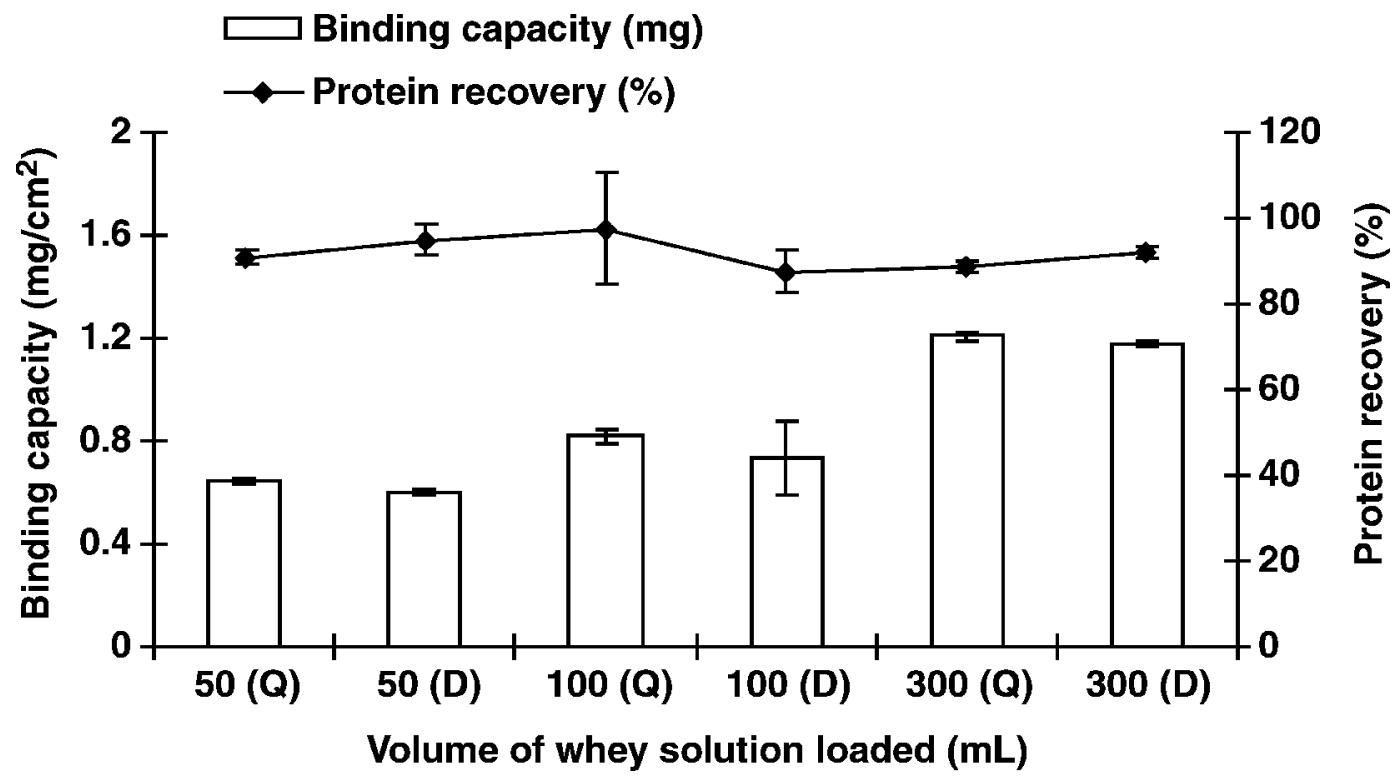

Figure 5. Binding capacity $\left(\mathrm{mg} / \mathrm{cm}^{2}\right)$ and total protein ( $\beta$-lactoglobulin, BSA, and $\alpha$-lactalbumin) recovered in permeate wash and eluate after loading varying amounts of a diluted whey solution (1 mg of protein/mL) onto both the strong (Q) and weak (D) anion exchange membranes (MA75). Error bars represent the range of binding capacities and protein recovery from duplicate trials. 


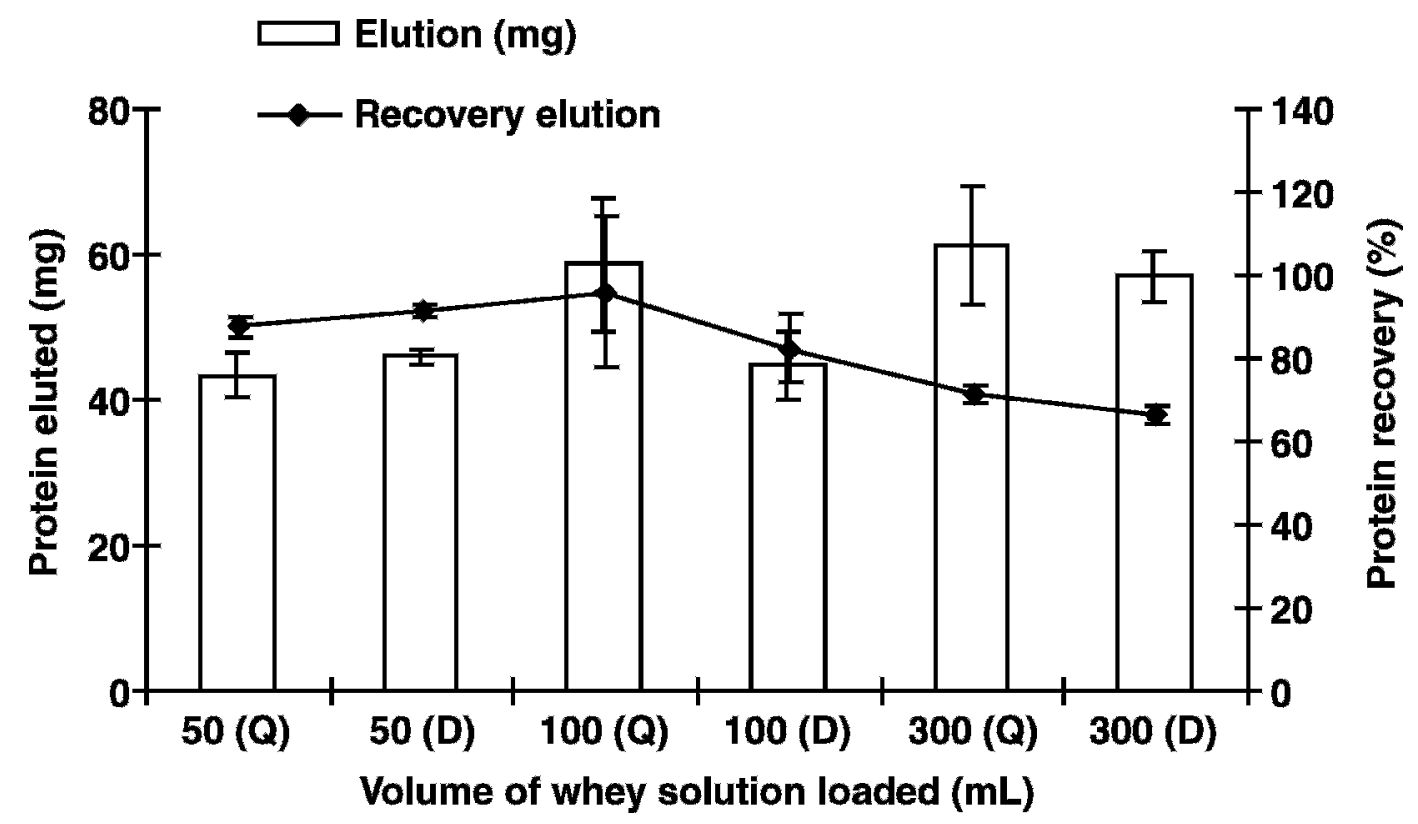

Figure 6. Total protein ( $\beta$-lactoglobulin, BSA and $\alpha$-lactalbumin) eluted $(\mathrm{mg})$ and total protein recovered in the elution fraction of the mass bound (\%) after loading varying amounts of a diluted whey solution (1 mg of protein/mL) onto both the strong (Q) and weak (D) anion exchange membrane (MA75). Error bars represent the range of eluted protein from duplicate trials.

protein binding. Whether the protein adsorbs preferentially to the membrane is not clear from this study. However, it is clear that the presence of ions reduces the binding capacity considerably. Reducing the effect of ions on binding capacity would require additional demineralization steps. Further work could be carried out on whey that has been demineralized or whey with increased ionic strength to determine the effects of ions on binding capacity of whey proteins to ion exchange membranes.

\section{CONCLUSIONS}

This study has shown that both strong and weak anion exchange membranes have a higher selectivity

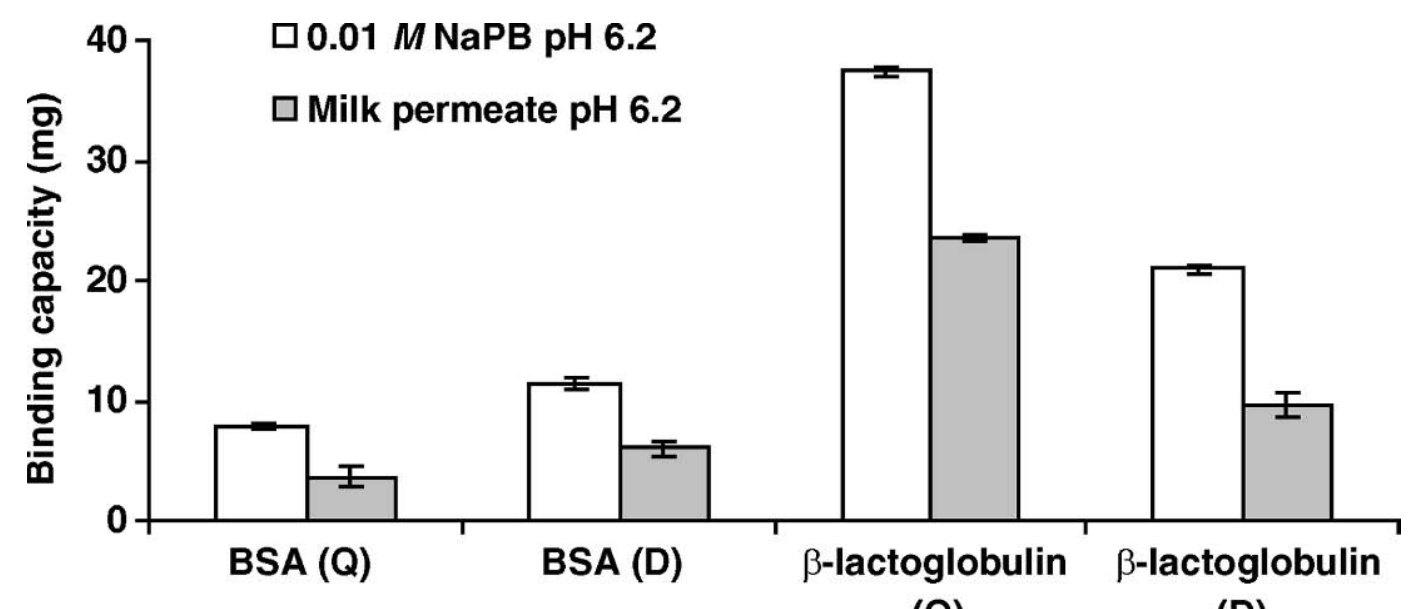

(Q)

(D)

Protein solution $(1 \mathrm{mg} / \mathrm{mL})$

Figure 7. Comparison of binding capacity $(\mathrm{mg})$ for standard BSA and $\beta$-lactoglobulin solutions in phosphate buffer and milk permeate when passed through the strong $(\mathrm{Q})$ and weak (D) anion exchange membranes (MA15). Error bars represent the range of binding capacities from duplicate trials. 
for $\beta$-lactoglobulin than the other major whey proteins and could therefore be used as a selective adsorption process. The main difference between the strong and weak anion exchange membranes is the binding capacity, with the weak exchanger having a slightly lower capacity. Importantly, it was shown that both the weak and strong anion exchange membranes have the same selectivity once the membranes have become saturated with whey proteins. The saturation point of the membranes differs in that the weak anion exchange membrane will saturate more quickly owing to its smaller binding capacity. Ion exchange membranes allow for the adsorption of $\beta$-lactoglobulin, $\alpha$-lactalbumin, and BSA initially; however, once a certain protein loading is achieved, $\beta$-lactoglobulin begins to displace $\alpha$-lactalbumin and BSA from the membrane. This competitive effect was also seen when binary solutions of $\alpha$-lactalbumin and BSA were studied, and in this case BSA was the stronger binding protein, in agreement with Weinbrenner and Etzel, (1994).

Having established that using ion exchange membranes to adsorb all 3 of the major whey proteins is complicated by the competitive effect of $\beta$-lactoglobulin at the point of membrane saturation, the next consideration would be to use these membranes in a cascade process. There is evidence that a 2 -step separation could be used to firstly remove $\beta$-lactoglobulin using an anion exchange membrane, which would remove its competitive effect, allowing for the recovery of $\alpha$-lactalbumin and BSA from the retentate by passing it through a second anion exchange membrane (Fuda and Jauregi, 2006).

This study showed that ion exchange membranes are a viable processing method with a high selectivity producing a relatively pure $\beta$-lactoglobulin elution fraction and the possibility of producing a permeate fraction enriched in $\alpha$-lactalbumin and BSA. Manipulation of loading volume, $\mathrm{pH}$, and elution gradient can produce individual protein streams. The current limitation of the process, particularly when trying to bind all 3 of the major whey proteins, is the low binding capacity of commercially available membranes.

It should be noted that the scale of these experiments was very small and that future studies are necessary to evaluate the effects of repeated cycling, including a more detailed evaluation of protein mass balance. Future work will consider the effect of heat treatments and ionic environment on the binding capacity and indi- vidual protein selectivity of the strong and weak exchangers.

\section{ACKNOWLEDGMENTS}

The authors would like to thank the Biotechnology and Biological Sciences Research Council and Volac International Ltd. for financial support.

\section{REFERENCES}

Adisaputro, I. A., Y.-J. Wu, and M. Etzel. 1996. Strong cation and anion exchange membranes and beads for protein isolation from whey. J. Liquid Chromatogr. Related Technol. 19:1437-1450.

Bhattacharjee, S., C. Bhattacharjee, and S. Datta. 2006. Studies on the fractionation of beta lactoglobulin from caesin whey using ultrafiltration and ion exchange membrane chromatography. J. Membr. Sci. 275:141-150.

Casal, E., A. Montilla, F. J. Moreno, A. Olano, and N. Corzo. 2006. Use of chitosan for selective removal of beta lactoglobulin from whey. J. Dairy Sci. 89:1384-1389.

Chiu, C. K., and M. K. Etzel. 1997. Fractionation of lactoperoxidase and lactoferrin from bovine whey using a cation exchange membrane. J. Food Sci. 62:996-1000.

de Wit, J. N. 1998. Nutritional and functional characteristics of whey proteins in food products. J. Dairy Sci. 81:597-608.

Drioli, E., and M. Romano. 2001. Progress and new perspectives on integrated membrane operations for sustainable industrial growth. Ind. Eng. Chem. 40:1277-1300.

Etzel, M. 1995. Whey protein isolation and fractionation using ion exchangers. Marcel Dekker Inc., New York, NY.

Fonteh, F. 2001. Role of Lactoperoxidase System in Raw Milk Preservation. The University of Reading, Reading, UK.

Fox, P., and P. L. H. McSweeney. 2003. Advanced Dairy Chemistry. Vol. 1. 3rd ed. Kluwer Academic, New York, NY.

Fuda, E., and P. Jauregi. 2006. An insight into the mechanism of protein separation by colloidal gas aphrons (CGA) generated from ionic surfactants. J. Chromatogr. B 843:317-326.

Kanekanian, A. D. A., and M. J. Lewis. 1986. Protein isolation using ion-exchangers. Pages 135-170 in Developments in Food Proteins. Vol. 4. B. J. F. Hudson, ed. Elsevier Appl. Sci. Publ., London, UK.

Skudder, P. 1985. Evaluation of a porous silica-based ion exchange medium for the production of protein fractions from rennet and acid whey. J. Dairy Res. 52:167-181.

Smith, P., R. Krohn, G. Hermanson, A. Mallia, F. Gartner, M. Provenzano, E. Fujimoto, N. Goeke, B. Olson, and D. Klenk. 1985. Measurement of protein using bicinchoninic acid. Anal. Biochem. 150:76-85.

Splitt, H., I. Mackenstedt, and R. Freitag. 1996. Preparative membrane adsorber chromatography for the isolation of cow milk components. J. Chromatogr. A 729:87-97.

Turhan, K. N., and M. R. Etzel. 2004. Whey protein isolate and alpha lactalbumin recovery from lactic acid whey using cation-exchange chromatography. J. Food Sci. 69:66-70.

Ulber, R., K. Plate, T. Demmer, H. Buchholz, and T. Scheper. 2001. Downstream processing of bovine lactoferrin from sweet whey. Acta Biotechnol. 21:27-34.

Weinbrenner, W. F., and M. Etzel. 1994. Competitive adsorption of alpha lactalbumin and bovine serum albumin to a sulfopropyl ion-exchange membrane. J. Chromatogr. A 662:414-419.

Zydney, A. L. 1998. Protein separations using membrane filtration: New opportunities for whey fractionation. Int. Dairy J. 8:243-250. 